\title{
BREEDING PERFORMANCE, SPAWNING AND NURSING OF BLACK CARP (MYLOPHARYNGODON PICEUS)
}

\author{
Md. Eilious Hosain*, Md. Nazmul Alam and Mohammed Zakir Hossain \\ WorldFish, Bangladesh \& South Asia, House 22B, Road 7, Block F, \\ Banani, Dhaka-1213, Bangladesh
}

\begin{abstract}
Successful induced breeding of black carp was performed by using Pituitary Gland (PG) extract and synthetic hormone Flash ${ }^{\mathrm{TM}}$. For PG, the female received two doses at the rate of $2 \mathrm{mg} / \mathrm{Kg}$ and $8 \mathrm{mg} / \mathrm{Kg}$ body weight respectively; where male received only single dose at the amount of $2 \mathrm{mg} / \mathrm{Kg}$ body weight. For Flash, the male and female was received only one dose at the amount of $0.3 \mathrm{ml} / \mathrm{Kg}$ body weight for male and $0.25 \mathrm{ml} / \mathrm{Kg}$ body weight for female respectively. The ovulation period was 12 hours for PG and 11 hours for Flash after lost injection. In total $6.1 \mathrm{Kg}$ of hatchling was obtained from $23 \mathrm{~kg}$ of female black carp under the two treatments. While, the ratio of hatchling and female fish body weight was $1: 4.28$ for PG and $1: 3.34$ for Flash. The study also indicates that the spawn Production of black carp and nursery operation ware profitable. In the spawn production, the profit rate was $872.76 \%$ ware observed and the cost benefit ratio recorded as 1: 8.72. In cases of profit from spawn production and nursery operation combined of black carp, the return was $247.95 \%$. While, cost benefit ratio was $1: 2.47$. For income generation through hatchery and nursery operation for sustainable aquaculture extensive study is needed in this regards.
\end{abstract}

Key words: Black carp, breeding, spawn, nursery operation, cost-benefit analysis

\section{INTRODUCTION}

There are namely natural, induced and strip spawning approaches are used for finfish seed production. In natural spawning, fish mature and spontaneously spawn in their natural habitat or in captivity. In induced spawning, either wild or captive brood stocks are induced to spawn through the use of a hormone or without hormone treatment but with environmental manipulation. The strip method is the manual stripping of eggs and sperm, and artificial fertilization, after hormonal treatment. Natural or induced spawning dominates the fish hatchery industry, as it is more effective than the strip method (Juario et al. 1984, Watson 1987, Liu 2000). In Bangladesh, tradi-tionally in the point of view of fish hatchery business, the seed and fry production technique of Indian major carps: Rui (Labeo rohita), Catla (Catla catla), Mrigal(Cirrhinus cirrhosus) and Kalibaush (Labeo calbasu) through induced breeding have

Been well developed and documented. As the first successful induced spawning in Bangladesh was performed by Ali (1967) in carps through hypophysation and then standardized by (Haque 1975, Islam and Chowdhury 1976, Ahmed 1983, and Alam 1983 etc.).

\footnotetext{
*Author for correspondence: <m.hosain@cgiar.org>.
} 
Bangladesh is an important biodiversity hotspot and enriched with more than 260 freshwater fishes, though many species are being commercially cultured. So far 12 exotic species have been introduced to Bangladesh (Rahman 2005) for commercial aquaculture. Both endemic like Indian major and minor carps, exotic fishes such as common carp, tilapia, catfishes as well as perches plays important role in aquaculture sector having enormously contributed to the total aquaculture and major production in closed water inland fisheries. In addition employment opportunity, income generation, empowerment of women, improves subsistence as a whole of sustainable aquaculture and improved livelihood status of fish farmer are recognized. Black carp also known as Snail carp was introduced for the first time in Bangladesh by the Department of Fisheries in 1983. A consignment of 2000 fry were brought by Chinese officials from Kwantung Province and were raised in ponds of Aquaculture Experimental Station at Mymensingh and the Fish Hatchery and Training Center at Raipur (Rahman 2005). It has been prescribed as one of the most suitable candidate Bangladesh for its fast growth rate and good table quality (Ameen 1987). It can grow up to $70 \mathrm{~kg}$ in weight (Peirong 1989). The fish uses the bottom layer of the ecosystem that is often unused in Bangladesh, so the species has a technical advantage in polyculture with surface and mid water feeder species (Ameen 1987). Black carp females are sexually matured in 5-8 years; however, males usually mature one year earlier than the females (Peirong 1989). The first successful induced breeding of the black carp was achieved in China with artificial ovulatory agents in 1963 (Shigang 1989). Though every hatchery owners of Bangladesh have limited stock of the species but they did not perform the breeding like other aquaculture species. The potentiality of commercial aquaculture of the species is promising but the research on fry production and fingerling rearing and their economy are still now scanty. Therefore, the present study aimed to be assessment of breeding performance and calculate hatchery economy and nursery operation on captive condition.

\section{MATERIAL AND METHODS}

Study site: The study was conducted in Dipanchal Agrofisheries Hatchery $\left(22^{\circ} 46.833^{\circ} \mathrm{N}\right.$ and $\left.90^{\circ} 38.909^{\circ} \mathrm{E}\right)$ at Bhola Sadar in Bhola district of Bangladesh. The hatchery was $12 \mathrm{~km}$ away from Bhola Sadar and situated on the bank of Meghna River. The study was performed between November 2013 and September 2014. The hatchery complex has two parts- one is the hatchery proper (20 decimal) where breeding activities were performed and another was the culture unit ( 9 acre) where brood rearing, nursing and culture were done. The hatchery proper possessed of one overhead tank, fourteen hatching jars, six circular tanks as well as four delivery tanks. River water also collected and then kept in a pond and used it for breeding and hatchery purposes. There were eleven ponds of which seven are brood fish pond of carps and catfish namely Pangus. 
Brood source: Total 50 yearlings of black carp were collected from fry market at Chachra of Jessore in 2007 then stocked in (1 yearling/5 decimals appox.) a hectare size pond. The brood were ready after six years of rearing.

Management of broods and brood pond: In the month of November 2013, the embankments and the pond bottom were cleaned and repaired manually. Quicklime was applied in the pond at the rate of $1.0 \mathrm{~kg} /$ decimal as initial dose before seven days of fertilization. Pond was fertilized with urea, triple super phosphate (TSP) and master oil cake at the rate of $150 \mathrm{~g} /$ decimal, 100 $\mathrm{g} /$ decimal $1 \mathrm{Kg} /$ decimal respectively. After seven days of fertilization brood fishes were released in the ponds at the density of $10 \mathrm{Kg}$ fish per decimal. Water depth of brood fish pond maintained from one to 1.5 meters. Partially water exchange was done regular basis using plastic pipe to keep the fish disease free and early maturation. To control unwanted fishes like tank goby, glassy fish and small prawn etc. Magic card at the rate of $30 \mathrm{~g} /$ decimal for 5 feet depth (the product of MEGA agrovet industries Bangladesh).

Breeding performance: For breeding male and female black carp were harvested in the early morning and kept at tanks separately 6-7 hours for conditioning. During condition period no feed was provided to keep their stomach free from foods. Before injection the broods were kept on wet foam to minimize the stress and the eyes were covered with cloth to free from movement. The single pair of black carp brood was injected with PG extract at the pectoral fin bases at $45^{\circ}$ angle. After 6 hours of first dose females received a second dose. Males received a single dose during the second dose of female. Another one pair of black carp brood was injected with synthetic hormone namely Flash at the pectoral fin bases at $45^{\circ}$ angle. In this case male and female received only one dose. After ovulation eggs were collected from the female in a bowl by stripping i.e., by giving gentle pressure on the abdomen of female. Then milt was collected from the male by applying the same procedure. The eggs and milts were mixed by using a feather for fertilization. The fertilized eggs were transferred to the hatching jar.

Management of black carp nursery: The nursery pond of black carp was 50 decimal of size and rectangular of shape. The dike and the bottom of the pond were cleaned and repaired manually. Quicklime was applied in the pond at the rate of $1.0 \mathrm{~kg} /$ decimal as initial dose before seven days of fertilization. The pond was fertilized with urea, triple super phosphate (TSP) and master oil cake at the rate of $150 \mathrm{~g} /$ decimal, $100 \mathrm{~g} /$ decimal and $1 \mathrm{Kg} /$ decimal respectively. To control harmful aquatic insects and undesirable zooplanktons and minute insects applied Delitics (Deltamethrin 1.75\%; products of FishTech BD. Ltd.) at the rate of $0.70 \mathrm{ml} /$ decimal for 4 feet water depth and applied two times before stocking of spawn in the pond. Spawn stocking density was $50 \mathrm{~g} /$ decimal. Feeding was done at the rate of $4 \mathrm{~kg} / 2.5 \mathrm{~kg}$ hatchling/ day for the first one week, $5 \mathrm{~kg}$ for the second weeks, $6 \mathrm{~kg}$ for the third week then $130 \mathrm{~kg}$ feed also used another 2 months rearing period. Selling of fry was started after 21 days nursing of fry. 
Data collection and statistical analysis: Data on pond lease value, embankments of bottom repairing cost, water exchange cost for brood pond, netting of pond, water expenses for hatching, Hormone, PG, medicine, marketing, miscellaneous and salary of technicians and labours cost were collected from register book and hatchery owner face to face interview. Data on different parameters of the study were measured, tabled and presented by using MS Word and MS Excel 2007.

\section{RESULTS AND DISCUSSION}

Breeding performances: In the present investigation, the successful breeding was performed among two pair of male and female of black carp by using PG and synthetic hormone name Flash. Artificial seed production of black carp in Bangladesh was reported by Kamal et al. (2006) and Sarder (2007). The average weight of male and female was $7.5 \mathrm{~kg}$ and $11.5 \mathrm{~kg}$ respectively, whereas they were same age group $6^{+}$. For PG treatment, the female was received two doses at the rate of $2 \mathrm{mg} / \mathrm{Kg}$ and $8 \mathrm{mg} / \mathrm{Kg}$ body weight respectively; Dose two was received apart from 6 hours after of first dose. In cases of male, the fish was received only single dose at the amount of $2 \mathrm{mg} / \mathrm{Kg}$, while the female receive her single dose (Table 1). Similar application of PG extract for breeding of carps were observed by Bhuiyan and Aktar (2011) in the hatcheries of Rajshahi district and Minar et al. (2012) in the hatcheries of Barisal district of Bangladesh. For using the Flash, the male and female was received only one dose at the rate of 0.3 $\mathrm{ml} / \mathrm{Kg}$ for male and $0.25 \mathrm{ml} / \mathrm{Kg}$ for female respectively (Table 1).

Table 1. Showing breeding performance of black carp in Dipanchal Agro-fisheries of Bhola, Bangladesh

\begin{tabular}{|c|c|c|c|c|}
\hline Parameters & $\begin{array}{c}\mathrm{PG} \\
\text { treatment }\end{array}$ & $\begin{array}{l}\text { Synthetic } \\
\text { hormone } \\
\text { treatment }\end{array}$ & Mean \pm SD & Total \\
\hline Number of Male & 1 & 1 & -- & 2 \\
\hline Number of Female & 1 & 1 & -- & 2 \\
\hline Age of Male & $6^{+}$ & $6^{+}$ & -- & - \\
\hline Age of Female & $6^{+}$ & $6^{+}$ & -- & - \\
\hline Weight of Male & 8 & 7 & $7.5 \pm 0.707$ & 15 \\
\hline Weight of Female & 12 & 11 & $11.5 \pm 0.707$ & 23 \\
\hline $1^{\text {st }}$ dose for male $[(\mathrm{mg} / \mathrm{k}) /(\mathrm{ml} / \mathrm{Kg})]$ & 2 & 0.3 & -- & -- \\
\hline $1^{\text {st }}$ dose for female $[(\mathrm{mg} / \mathrm{k}) /(\mathrm{ml} / \mathrm{Kg})]$ & 2 & 0.25 & -- & -- \\
\hline $2^{\text {nd }}$ dose for female $[(\mathrm{mg} / \mathrm{k}) /(\mathrm{ml} / \mathrm{Kg})]$ & 8 & -- & -- & -- \\
\hline Ovulation period (hrs) & 12 & 11 & $11.5 \pm 0.707$ & 23 \\
\hline Weight of hatchling (kg) & 2.8 & 3.3 & $3.05 \pm 0.353$ & 6.1 \\
\hline Ratio & $1: 4.28$ & $1: 3.34$ & & \\
\hline
\end{tabular}


The more or less of identical doses of synthetic hormone Ovupin solution used for carp seed production in Nimgachi Fish Hatchery and Training Center, Sirajgonj, Bangladesh and was also reported by Mondol et al. (2014). In the present experiment, the mean ovulation period was 11.5 hours and for PG treatment, it was 12 hours; whereas 11 hours of ovulation period was observed for Flash treatment (Table 1). The more or less ovulation period was also observed by Mondol et al. (2014) for Indian major carps and minor carps. In the present study, the total $6.1 \mathrm{Kg}$ of hatchling was found from $23 \mathrm{Kg}$ of female black carps under two treatments. For extracted PG hormone treatment, $2.8 \mathrm{Kg}$ of hatchling was found from $12 \mathrm{Kg}$ of female fish, while the ratio of hatchling and body weight of female fish was $1: 4.28$. In cases of synthetic hormone Flash treatment, $3.3 \mathrm{Kg}$ of hatchling was found from $11 \mathrm{Kg}$ of female fish, whereas the ratio of hatchling and body weight of female fish was $1: 3.34$ (Table 1). The investigations indicate that the synthetic hormone Flash treatment was less hazardous than PG treatment for big black carp fishes.

Cost of brood pond operation: Expenditure of brood pond operation has been presented in the Table 2. Among various expenditure groups the pond lease value was dominant and occupied by $61 \%$ of total expenditure and cost was $1253 \mathrm{Tk}$.

Table 2. Showing expenditure of brood pond operation of black carp and inputs for per kg spawn production in the hatchery management of Dipanchal Agro-fisheries in Bhola, Bangladesh

\begin{tabular}{llcccc}
\hline Issue & Unit & $\begin{array}{c}\text { Unit cost } \\
(\mathrm{Tk})\end{array}$ & $\begin{array}{c}\text { Total } \\
\text { units }\end{array}$ & Total cost & $\begin{array}{c}\text { Percentage } \\
(\%)\end{array}$ \\
\hline $\begin{array}{l}\text { Pond lease (7 months) } \\
\text { Pond bottom and dike }\end{array}$ & Decimal & 44.75 & 4 & 1253 & 61 \\
repair (7 months) & Decimal & 21.83 & 4 & 611 & 30 \\
Liming & Decimal & 13 & 4 & 52 & 2 \\
Fertilizations & Decimal & 15 & 4 & 60 & 3 \\
Feeding & Kg & 0 & 0 & 0 & 0 \\
Control of unwanted & Kg & 4.5 & 4 & 18 & 1 \\
species & \&decimal & & & & \\
Medicine & - & - & - & 20 & 1 \\
Netting & 10 & 4 & 40 & 2 \\
Total (TK) & & & 2054 & $100 \%$ \\
\hline Brood rearing cost (Per Kg Spawn) =Total brood rearing cost (2054) $\div$ & 337 \\
Total produced (6.1) Spawn & & & \\
\hline
\end{tabular}

The second dominant criteria of expense was pond bottom and dike repair and comprised of $30 \%$ total expenditure as well as cost was $611 \mathrm{Tk}$; and 
followed by $3 \%$ and $60 \mathrm{Tk} ; 2 \%$ and $52,40 \mathrm{Tk} ; 1 \%$ and $20,18 \mathrm{Tk}$ were also observed non dominant expenditure as well as used for the purposes of application of fertilizations, liming, netting, medicine and control of unwanted species respectively (Table 2 ).

Cost of hatchery operation: The expenditure of hatchery operation cost, salary of technician and labours and other inputs for per Kg spawn production of black carp of Dipanchal agro-fisheries have been presented in the Table 3. The dominant cost was $35 \%$ and $421 \mathrm{Tk}$ spent for the purposes of salary of technicians and labours of the hatchery. Whereas, the depreciation of hatchery fixed assets and repair of hatchery complex and others apparatuses were constitute of $3 \%$ and $32 \mathrm{Tk}$ and $13 \%$ and $155 \mathrm{Tk}$ respectively. While the water expenses for hatchling cost was $61 \mathrm{Tk}$ and comprised of $5 \%$ of total expenditure. In cases of PG and hormone cost were 131 and $292 \mathrm{Tk}$ respectively and this group occupied by $35 \%$ of total expenditure. $96 \mathrm{Tk}$ was also used for the purposes of oxygen and polybag for packaging of spawn. For the purposes of marketing and miscellaneous $17 \mathrm{Tk}$ was used (Table 3).

Cost of nursery operation: Nursery operation cost of black carp is also shown in the Table 4. Among nursery operation cost of black carp, the major cost group was the salary of labour $28000 \mathrm{Tk}$ and comprised of $40 \%$ of total operation cost. Another major cost group was feeding and $12220 \mathrm{Tk}$ spent and constituted of $17 \%$ of total nursery operation expenditure. $15 \%$ of total nursery operation cost was for oxygen and poly bag for packaging of fry/fingerling (Table 4).

Table 3. Showing expenditure of hatchery operation cost, salary of technician and labour and inputs for per $\mathrm{Kg}$ spawn production of black carp of Dipanchal Agrofisheries in Bhola, Bangladesh

\begin{tabular}{lcc}
\hline Issue & $\begin{array}{c}\text { Total } \\
\text { cost }\end{array}$ & $\begin{array}{c}\text { Percentage } \\
(\%)\end{array}$ \\
\hline Depreciation of Hatchery fixed asset & 32 & 3 \\
Repair of hatchery complex and others apparatuses & 155 & 13 \\
Technicians and labours salary & 421 & 35 \\
Water & 61 & 5 \\
PG & 131 & 11 \\
Hormone & 292 & 24 \\
Oxygen and poly bag & 96 & 8 \\
Marketing & 7 & 0 \\
Miscellaneous & 10 & 1 \\
Total(Per Kg) & 1205 & $100 \%$ \\
\hline Total spawn production cost $=$ Total spawn $\times$ Total cost/kg spawn & \\
$=(6.1 \times 1205)$ & & \\
\hline
\end{tabular}


The cost of pond lease and pond bottom and dike repair were $8950 \mathrm{Tk}$ and $4367 \mathrm{Tk}$ as well as occupied of $13 \%$ and $6 \%$ of total operation cost respectively. The water exchange cost was $2208 \mathrm{Tk}$. whereas, $650 \mathrm{Tk}$ also used for liming of pond. While, Fertilizations and medicine cost were 1800 and 730 Tk respectively. $900 \mathrm{Tk}$ was also spent for the purposes of marketing of fry and fingerling of black carp (Table 4).

Table 4. Showing expenditure of black carp nursery operation cost $(2.5 \mathrm{Kg}$ Hatchling) of Dipanchal Agro-fisheries in Bhola, Bangladesh

\begin{tabular}{llcccc}
\hline Issue & Unit & $\begin{array}{l}\text { Unit } \\
\text { cost }\end{array}$ & $\begin{array}{l}\text { Total } \\
\text { units }\end{array}$ & $\begin{array}{l}\text { Total } \\
\text { cost }\end{array}$ & $\begin{array}{l}\text { Percentage } \\
\text { (\%) }\end{array}$ \\
\hline Pond lease (4 months) & decimal & 44.75 & 50 & 8950 & 13 \\
Pond bottom and dike repair (4 & decimal & 21.83 & 50 & 4367 & 6 \\
months) & Liter & 69 & 32 & 2208 & 3 \\
Water exchange & decimal & 13 & 50 & 650 & 1 \\
Liming & decimal & & 50 & 1800 & 3 \\
Fertilizations & decimal & 14.60 & 50 & 730 & 1 \\
Medicine & kg & 52 & 235 & 12220 & 17 \\
Feeding & & 7000 & 4 & 28000 & 40 \\
Labour salary (4 months) & & & 445 & 10680 & 15 \\
Oxygen and poly bag & & & & 900 & 1 \\
Marketing & & & & 70505 & $100 \%$ \\
\hline Total & & & & & \\
\hline
\end{tabular}

Selling statas of black carp fry/fingerling: Selling and distribution status of black carp fry/fingerling of Dipanchal agro-fisheries have been presented in the Table 5. Dipanchal agro-fisheries hatchery operate black carp nursery and produced $197 \mathrm{Kg}$ and 445000 individual and sold out by worth of $224050 \mathrm{Tk}$ as well as distribute the fry/fingerling among 9 districts of Bangladesh. On the basis of percentage composition of distribution of black carp fry/fingerling $27 \%$ distribute in Laxmipur and followed by $18 \%$ in Bhola, $16 \%$ in Noakhali, Comilla and Jessore, $2 \%$ in Chittagong, Cox`s bazar and Feni as well as 1\% in Barisal in the occurrence of total distribution. The study, total $197 \mathrm{~kg}$ of fry/fingerling found from $2.5 \mathrm{Kg}$ of hatchling. Among total weight of black carp fry/fingerling, the range of distribution was from $3.5 \mathrm{~kg}$ in Barisal to $50 \mathrm{Kg}$ in Bhola. Whereas, the individual weight of black carp fry/fingerling was diverse from $0.33 \mathrm{~g} /$ individual in Noakhali to $0.7 \mathrm{~g} /$ individual in Barisal. In cases of, the individual selling value was fluctuated from $0.4 \mathrm{Tk} /$ individual in Noakhali to $0.8 \mathrm{Tk} /$ individual in Barisal. The selling status comprised of $24 \%$ in Laxmipur and followed by $22 \%, 21 \%, 13 \%, 12 \% 2 \%$ in Jessore, Bhola, Noakhali, Comilla, Chittagong, Cox`s bazar, Feni and Barisal respectively (Table 5). 
Table 5. Showing selling and distribution status of black carp fry/fingerling of Dipanchal agro-fisheries in Bhola, Bangladesh

\begin{tabular}{|c|c|c|c|c|c|c|c|}
\hline \multirow[t]{2}{*}{ Place } & \multirow{2}{*}{$\begin{array}{l}\text { Total weight } \\
\text { (Kg) }\end{array}$} & \multirow{2}{*}{$\begin{array}{l}\text { Individual } \\
\text { weight (g) }\end{array}$} & \multirow{2}{*}{$\begin{array}{l}\text { Number of } \\
\text { ry/fingerlin६ }\end{array}$} & \multirow{2}{*}{$\begin{array}{l}\text { Unit value } \\
\qquad(\mathrm{Tk})\end{array}$} & \multirow{2}{*}{$\begin{array}{c}\text { Total sell } \\
\text { value (Tk) }\end{array}$} & \multicolumn{2}{|c|}{ Percentage (\%) } \\
\hline & & & & & & $\begin{array}{c}\text { Value } \\
\text { (Tk) }\end{array}$ & Number \\
\hline Noakhali & 23.5 & 0.33 & 70000 & 0.40 & 28000 & 13 & 16 \\
\hline Laxmipur & 44.4 & 0.37 & 120000 & 0.45 & 53640 & 24 & 27 \\
\hline Chittagong & 3.7 & 0.37 & 10000 & 0.45 & 4470 & 2 & 2 \\
\hline Cox`s bazar & 3.7 & 0.37 & 10000 & 0.45 & 4470 & 2 & 2 \\
\hline Feni & 3.7 & 0.37 & 10000 & 0.45 & 4470 & 2 & 2 \\
\hline Comilla & 23.5 & 0.33 & 70000 & 0.40 & 28000 & 12 & 16 \\
\hline Jessore & 41 & 0.59 & 70000 & 0.70 & 49000 & 22 & 16 \\
\hline Bhola & 50 & 0.62 & 80000 & 0.60 & 48000 & 21 & 18 \\
\hline Barisal & 3.5 & 0.70 & 5000 & 0.80 & 4000 & 2 & 1 \\
\hline Total & 197 & & 445000 & & 224050 & 100 & 100 \\
\hline Range & $3.5-50$ & $0.33-0.7$ & & $0.4-0.8$ & & & \\
\hline Mean $\pm \mathrm{SD}$ & $21.89 \pm 19.35$ & $0.45 \pm 0.14$ & & $0.52 \pm 0.15$ & & & \\
\hline
\end{tabular}

Cost benefit analysis: Cost benefit analysis and their ratio of black carp spawn production and nursery operation of Dipanchal agro-fisheries is shown in the Table 6. Total expenditure $1542 \mathrm{Tk} / \mathrm{Kg}$ spawn was found the present study. Whereas, the brood pond operation cost was $337 \mathrm{Tk} / \mathrm{Kg}$ spawn. While, Hatchery operation and marketing cost was $1205 \mathrm{Tk} / \mathrm{Kg}$ spawn. The present study, the selling value was $15000 \mathrm{Tk} / \mathrm{Kg}$ spawn. Higher sell value of black carp spawn was reported by Sharif and Abdulla-Al-Asif (2015) from Jessore in Bangladesh. In these cases, the profit from spawn selling was $13458 \mathrm{Tk} / \mathrm{Kg}$ spawn. The profit rate was $872.76 \%$ and the cost benefit ratio recorded $1: 8.72$. The recorded return rate was found higher than that of the findings of Kumar et al. (2008). In addition to, the black carp spawn is rear in Bangladesh; only few hatcheries produced black carp spawn. So, spawn production business of black carp is more profitable. Hossain and Humayon (2001) reported that carp spawning to fry rearing generated higher net returns (Tk 124895) than that of fry to fingerling rearing (Tk 96660) respectively. Total brood pond operation cost was 2054 Tk and comprised $3 \%$ of total expenditure of spawn production and nursery operation cost. While, $7350 \mathrm{Tk}$ also expenses for hatchery operation marketing purposes and occupied of $9 \%$ of total expenditure on the occurrence of percentage composition. The dominant expenditure $88 \%$ and $70505 \mathrm{Tk}$ were used for the purposes of nursery operation of black carp. Dipanchal agrofisheries earns $54000 \mathrm{Tk}$ from sell of spawn and $224050 \mathrm{Tk}$ from fry/fingerling sell of black carp respectively which comprised of $19 \%$ and $81 \%$ of total income. 
In cases of profit from spawn production and nursery operation of black carp, the return was $198141 \mathrm{Tk}$ and $247.95 \%$. While, cost benefit ratio was $1: 2.47$. Katiha, (2001) reported that the cost benefit ratio (4.71) for fry fingerling rearing in India which was higher than from our findings. Thus, their study was more or less consistent to the present study for the point of view of spawn production and fry/ fingerling rearing of black carp.

Table 6. Showing cost benefit analysis and their ratio of black carp spawn production and nursery operation of Dipanchal agro-fisheries in Bhola, Bangladesh

\begin{tabular}{|c|c|c|c|c|}
\hline \multicolumn{2}{|c|}{ Description } & \multirow{2}{*}{\begin{tabular}{l}
\multicolumn{1}{c}{ Issue } \\
Brood pond operation cost \\
{$[$ Spawn $(\mathrm{kg} / \mathrm{Tk})]$}
\end{tabular}} & \multirow{2}{*}{$\begin{array}{c}\text { Purposes } \\
(\mathrm{Tk})\end{array}$} & \multirow{2}{*}{$\begin{array}{c}\text { Percentage } \\
(\%)\end{array}$} \\
\hline \multirow{6}{*}{$\begin{array}{l}\text { Per kg } \\
\text { spawn } \\
\text { production } \\
\text { and selling }\end{array}$} & \multirow{3}{*}{ Expenditure } & & & \\
\hline & & $\begin{array}{l}\text { Hatchery operation and } \\
\text { marketing cost [Spawn }(\mathrm{kg} / \mathrm{Tk})]\end{array}$ & 1205 & 78 \\
\hline & & Sub total & 1542 & 100 \\
\hline & Income & Spawn sell $\quad(\mathrm{Kg} / \mathrm{Tk})$ & 15000 & \\
\hline & Profit & (Income- Expenditure) & 13458 & 872.76 \\
\hline & Ratio & Cost : Benefit & $1: 8.72$ & \\
\hline \multirow{9}{*}{$\begin{array}{l}\text { Total } \\
\text { spawn } \\
\text { production } \\
\text { and } \\
\text { nursery } \\
\text { operation } \\
\text { and their } \\
\text { selling }\end{array}$} & \multirow{4}{*}{ Expenditure } & Brood pond operation cost & 2054 & 3 \\
\hline & & $\begin{array}{l}\text { Hatchery operation and } \\
\text { marketing cost }\end{array}$ & 7350 & 9 \\
\hline & & Nursery operation cost & 70505 & 88 \\
\hline & & Sub total & 79909 & $100 \%$ \\
\hline & \multirow{3}{*}{ Income } & Spawn sell $(3.6 \times 15000)$ & 54000 & 19 \\
\hline & & Fry/ fingerling sell & 224050 & 81 \\
\hline & & Sub total & 278050 & $100 \%$ \\
\hline & Profit & (Income- Expenditure) & 198141 & 247.95 \\
\hline & Ratio & Cost :Benefit & $1: 2.47$ & \\
\hline
\end{tabular}

In the present study, it was observed that black carp responded to extract of PG and synthetic hormone Flash and successful breeding was occurred. Spawn production and nursery operation of black carp were profitable. Rahman (2005) reported the species (Black carp) attained an average weight of 1587 gm with few specimens attaining over $4200 \mathrm{~g}$ during 13 month of rearing period and the species provided with highly developed molariform teeth, which are used for crushing of snails. In the point of view of commercial aquaculture or confined fish poly culture system the species may introduce at low stocking density for grazing of molluscan fauna of the pond aquaculture system. Therefore, extensive research is needed by stocking black carp in fish pond poly culture system and 
in relation to snail control and conservation of molluscan fauna to minimize the concern of freshwater pond molluscan fauna in commercial aquaculture of Bangladesh.

Acknowledgements: The authors are grateful to Mr. M A Zaher Hatchery owner, Mr Abu Taher Dulal Manager cum operator and other staffs of Dipanchal Agrofisheries (Hatchery project) for their assistance and support to carry out the present study.

\section{LITERATURE CITED}

AHMED, M.K. 1983. Induced breeding of Indian major carps, Chinese carps and Catfish. Freshwater Fish Research Station Chandpur, Bangladesh. pp. 44-52.

ALAM, A.K.M.A. 1983. Low cost hatchery. Adam News 10(L): 27-33.

ALI, M.H. 1967. Induced breeding of major carps in ponds by pituitary hormone injection. Agric. Inform. Serv., Dhaka. pp. 23-26.

AMEEN, M. 1987. Fisheries Resources and Opportunities in Freshwater Fish Culture in Bangladesh. DANIDA Project Report, NRD-II Project, Noakhali, pp. 208-209.

BHUIYAN, A.S. and AKTAR, N. 2011. Observation on the Induced Spawning Practices in the Hatcheries of Rajshahi District of Bangladesh. J. Life Earth Sci., Vol. 6: 65-68.

HAQUE, K.A. 1975. Some observations on the induced spawning of major carps by pituitary hormone injection, Freshwater fish. Res. Sta. Chandpur. Bull. 1: 19-33.

HOSSAIN, M.M. and HUMAYON, N.M. 2001. Profile of Key Aquaculture Practices and Fishing Technologies in Bangladesh. Unpublished report submitted to the WorldFish Center, Penang, Malaysia.

ISLAM, M.Z. and CHOWDHURY, A.Q.1976. Induced spawning of major carps for commercial production of fry for fish seed in Bangladesh. Bangladesh J. Zool. 4(2): 51-61.

JUARIO, J.V., DURAY, M.N., DURAY, V.M., NACARIO, J.F. and ALMENDRAS, J.M.E. 1984. Induced breeding and larval rearing experiments with milkfish Chanos chanos (Forsskal) in the Philippines. Aquaculture 36: 61-70.

KAMAL, D., SIDDIQA, A. AND FERDOUS, K.S. 2006. Effect of Different Hormone Treatments on the Breeding Success of the Exotic Black Carp, Mylopharyngodon piceus. Bangladesh J. Zool. 34(2): 257-268.

KATIHA, K.P. 2001. Profile of Key Aquaculture Practices and Fishing Technologies in India. Unpublished report submitted to the World Fish Center, Penang, Malaysia.

KUMAR, P. DEY, M. M. and BARIK, N. K. 2008. Farm-economics of Genetically Improved Carp Strains in Major Asian Countries and Carp Seed Price Policy Model. Agricultural Economics Research Review. Vol. 21 (Conference Number) pp 395-406.

LIU, F.G., LIN, T.S., HUANG, D.U., MEEI-LING, P. and LIAO, I.C. 2000. An automated system for egg collection, hatching, and transfer of larvae in a freshwater finfish hatchery. Aquaculture 182: 137-148.

MINAR, M.H., SHAMSUDDIN, M.M.G.U., BABLU, M.M.G.U. and Bhuyan S.I. 2012. Induced Spawning Practices of Different Fishes in the Hatcheries of Barisal District, Bangladesh. Trends in the Fisheries Research. Vol. 1 No. 2: 14-17. 
MONDOL, M.R.K. PROVHAT, S.J. and HOSSAIN. M.A. 2014. Use of a Single Intramuscular Injection of a Synthetic Hormone Analogue, $\mathrm{O}$ vupin for Commercial Carp Seed Production in Bangladesh. Sains Malaysiana 43(5): 683-687.

PEIRONG, S. 1989. The biology of major freshwater cultivated fishes in China. In: Integrated Fish Farming in China. Network of Aquaculture Centres in Asia and the Pacific (NACA), Bangkok, pp. 2-15.

RAHMAN, A.K.A. 2005. Freshwater Fishes of Bangladesh, 2nd ed., Zool. Soc. Bangladesh, Dhaka. Bangladseh. Pp 27.

SARDER, R. 2007. Freshwater fish seed resources in Bangladesh, pp. 105-128. In: M.G. Bondad-Reantaso (ed.). Assessment of freshwater fish seed resources for sustainable aquaculture. FAO Fisheries Technical Paper. No. 501. Rome, FAO. 2007. 628p.

SHARIF, B.M.N. and ABDULLA-AL-ASIF. 2015. Present status of fish hatchlings and fry production management in greater Jessore, Bangladesh. International Journal of Fisheries and Aquatic Studies. 2(5): 123-127.

SHIGANG, Yu. 1989. Artificial propagation of Black Carp, Grass Carp, Silver Carp and Bighead Carp. Integrated Fish Farming in China. Network of Aquaculture Centres in Asia and the Pacific (NACA), Bangkok, Thailand, pp. 33-50.

WATSON, L.C. 1987. Spawning and hatching Atlantic tomcod. Prog. Fish-Cult. 49: 69-71. 